\title{
The Passive Voice Construction of Horong Ni Hula Hula Utterances in Batak Toba Wedding Ceremony
}

\author{
Posma Siahaan ${ }^{1, *}$ Didik Santoso ${ }^{2}$ Anni Pulungan ${ }^{3}$ \\ ${ }^{1,2,3}$ Universitas Negeri Medan \\ *Corresponding author. Email: poslamsagala220211@gmail.com
}

\begin{abstract}
This research dealt with the passive voice construction of Horong Ni Hula Hula utterances in Batak Toba wedding ceremony, the objectives of the study was to analyze what constructions of passive voice are used by Horong Ni Hula Hula utterances in Batak Toba wedding ceremony. This research is conducted by using descriptive qualitative design. The data were collected through observation by taking wedding video record. The findings of this study showed that: there are two types of passive voice in Batak Toba utterances, they are passive voice with definite agents and passive voice with indefinite agents.
\end{abstract}

\section{Keywords: Construction of Passive Voice, Horong Ni Hula Hula Utterances, Batak Toba Wedding Ceremony.}

\section{INTRODUCTION}

Indonesia is a multicultural country which has various ethnicities, religions, races, cultures, and dialects. This diversity is one of the characteristics and is the main point for Indonesian State to introduce its country to other countries. One of them is the regional language which always has its own word structure that differentiates among one regional language and another regional language in Indonesia.

The writer in this study set limits on her research regarding on the construction of the one of the languages in one of the island in Indonesia, namely North Sumatera. North Sumatra is a multiethnic province. The Malay people are regarded as the native people of this province. The Javanese reside around Deli Serdang Regency, including Medan, while the west coast of the province is mainly inhabited by Pakpak, Mandailing and Minangkabau people. The central region around Lake Toba, is predominantly inhabited by Bataks. Nias people reside mostly in Nias Island and the surrounding islands.

Batak Language is one of the languages used by Batak tribe in Indonesia for their communication in their community. Batak Language has so many types, namely Batak Toba Language, Batak Karo Language, Batak Mandailing Language, Batak Angkola Language, Batak Pakpak Language, and Batak Simalungun Language. In this research, the researcher was interested in to research Batak Toba Language (BTL) utterances.
Batak Toba tribe is one of the famous tribes in the North Sumatera Province. This tribe is known of their loud way for speaking. Many people say that Batak Toba people speak like someone who is angry. However, this has become a characteristic of the Batak Toba people who have the habit of looking for family or relationship with same clan. This habit of loud voices is also based on their place of residence in the mountains where in communicating, they should use loud voices.

According to Badaruddin.2013 said that Batak Toba gets stereotyped as "rough" people, especially in terms of narrative language. Batak Toba people have attitude that an expansion is so strong that they pay less attention to other people's feelings. As we know, human need other human in their life, during their process of communication, people think polite or impolite words to use because politeness itself can support the communication smoothly.

In expressing their politeness the Batak Toba people do not use soft pronunciation but they use more polite words or we can called it with euphemism words. Kate Burridge. 2012 stated that euphemism as expression that sound sweet and inoffensive as alternatives terms of speakers or writers that they prefer not to use in a specific communication process or occasion. Asmah. 2008 said that: "Penggunaan eufemisme bukan saja untuk melembutkan kata kata yang agak kasar, sebaliknya eufemisme digunakan sebagai satu strategi berbahasa yang sopan untuk tidak menyinggung hati dan perasaan orang lain." 
The marriage ceremony in Batak tribe is one that is quite long and complicated in its implementation. Not only related to the traditional procession, but Batak customs are very strict in matters of marriage with their own tribe, There are several uniqueness of The Batak Toba people which are very interesting, namely:

- Married with Pariban.

The ideal marriage for Batak Toba is a marriage with pariban. Pariban can be called by cousin. Batak Toba people think that their cousin is their soul mate and it is a good thing to marry their own cousins. In Batak Toba people, marriage with their cousin called with pariban has a goal to strengthen the ties of brotherhood between two close families into one.

- Martarombo

Indonesia do not have a uniform nomenclature system as in the western families who use a surname after their name, however, in certain tribes, the use of the surname must be given to their lineage. This is known as the clan. The clan is the name of the alliance of people who are brothers, blood relatives, descended according to the father's line, who have inherited names from generation to generation. Martarombo is one of Batak Toba people habitual for looking family relationship with people who have the same clan. If you are a Bataknese and you got to know someone who is Bataknese and you have a same clan, so that you will try to make a relationship with them.

- Tuhor

In Batak Toba Marriage, the man is responsible for all costs incurred during the wedding ceremony. Tuhor is called by money, the purpose of this money is to buy a woman, this money will be used for all purposes during the wedding. Level of Tuhor is depended on Woman's level education, if the woman has a high education and jobs, so that the exchange rate will also be more.

Even though in Batak Toba's life and language style community is harsh, but in fact, The Batak Toba people really glorify the values of politeness in their customs and in the surrounding community. This is proven when they perform their traditional ceremonies such as the death ceremony, marriage, and even the birth of child, they have great respect for their relatives or for people who are older than them. The research was applied in the Batak Philosophy, namely Dalihan Na Tolu diversion, namely: somba marhula hula, elek marboru and manat mardongan tubu.

Sianipar (2012:12-15) gives some examples of the attitude and daily activity of Batak Toba into eight parts, such as:
1. Appreciate the principle of life "habatahon", the attention and commit the message (tona), agreement (padan), and law (uhum).

2. The self-esteem is very high, dynamic, can be categorized as aggressive person and do not want abused by others.

3. In general, Batak Toba people are extrovert and do not like to hold grudges.

4. Batak Toba people have high work spirit and willing to work hard.

5. In Principle, Batak Toba people belong to members of the public who live work hand in hand.

6. Batak Toba people love to sing a song and dance Tor-tor.

7. Batak Toba people like to speech and intelligent, do not shy / hesitant to express their idea.

8. Mothers derived from Toba tribes loyal to their family.

As we know, Batak Toba tribe has a unique in their language in communication. They usually use an inversion language which is put the verb before the subject in their communication. It is as one of their characteristic in their language. In the Fact, Batak Toba Language (BTL) structure dominantly in inversion type that is why it is called as inverted language. Inversion is a sentence which the order of Subject (S) and Verbs (V) are exchanged. In the Normal Structure, Subject and Verb is placed in sequence, but in this research, the verb can be put before the subject.

Passive is used when the focus is on an action. It can be an important matter if we know the doer of the action, but in the passive sentences with indefinite agents, the doer is not necessary to know because the doer is not known perfectly. Geoffrey Leech (1973:257) "passive is used to describe the type of verb phrase which contains the construction $\mathrm{Be}+$ Past Participle; and also to describe the type of clauses in which a passive verb phrase occurs." In the other statement, passive was written by sentences.

In this case, the writer did pre investigation in the Batak Toba Wedding Ceremony by observing Horong Ni Hula Hula utterances in Passive Voice, so that, the writer found her preliminary data which was strengthened by Horong Ni Hula hula utterances that is shown the construction of passive voice, for example

(Utterances from speaker of groom's family) called by Parsinabung from groom's family:

[1] Dijoloni, ro do hami mambuan songon sibua-bua $i$, sai anggiat ma mamboan na uli, mamboan na denggan di angka partuturonna. tung Songgonnon 
pena boi dipatupa hami di hita namamboan aek na uli, mamboan aek na denggannon.

According to data (1) Parsinabung of groom utterances, the writer found passive voice sentence, such as:

$\begin{array}{ccc}\frac{\text { tung Songgonon }}{\text { Conj }} & \frac{\text { penaboi }}{S} & \text { dipatupa } \\ \text { Even though } & \text { this } & \text { is given }\end{array}$

hami di hita namamboan aek na

O Comp

by us

uli,mamboan aek na denggan non.

[even though, this is given by us to those of us who bring clear water, to bring good water]

The sentence is a kind of subordinate clause because it is use the word tung songgonon that is a kind of conjunction, then followed by pena boi refers to meals which are brought by groom's family to bride house, pena boi here as Subject in passive (S), and then dipatupa means is given as Verb (V), then hami means by us, in passive by us is the doer of the action, so in this utterance of Horong Ni Hula Hula, this utterances is a kind of passive voice with definite agents, and the construction is Conj S V O.

[2] Parsinabung from groom's family: Otik sosadia sibua-bua i naboi dipasahat

$\begin{array}{ccc}\text { Conj } & S & V \\ \text { May } & \text { the food } & \text { is being brought } \\ \text { hami } & \text { tu hamuna } & \text { saipanggabean }\end{array}$

o

By us to you

parhorasan tu sude hamuna.

[may the food is being brought by us to you, may it will be a blessing to all of us]

From data 2, still Parsinabung or groom's speaker utterance using passive voice. In this case, we can see that the speaker of the groom hoped that the food that is brought can be a blessing to all family especially for the bridegroom's families. From the data is also kind of subordinate clause, it is use otik sosadia means may that has a meaning hope, it is a Conjunction (Conj), then followed by sibua-buai (the food) as Subject (S), then naboi dipasahat (is being brought) as Verb passive (V), hami (by us) as Object in passive or we can say (by phrase) the doer of the action $(\mathrm{O})$, this utterance also a kind of passive voice with definite agents. So the construction of the data is Conj S V O.

\section{LITERATURE REVIEW}

Sentence is a string of words that is mixed and combined become one string. A sentence is consisted of words, phrases, and also clauses. A good sentence must have a subject and a full verb as its predicate on it, sentences also have a meaning and it must be illogical. According to Ruby Level (2001:406) "sentence is a group of words with two main parts: a complete subject complete predicate."

Bollinger (1975:156) states that the traditional definition of a sentence is the minimum part of language that expresses a complete thought, and certainly some sense of completeness is essential to it. In the sentence, there are the differences between the deep and surface structure. The surface structure of a sentence is its grammatical form, while the deep structure is understood as its meaning.

The passive voice requires a "double verb" and will always consist of a form of the verb "to be" and the past participle (usually the "en/ed/t" form) of another verb. Example: is kicked. Passive voice is the verb form, where the subject receives the action. Alexander (2006:241) state that active voice and passive voice refer to a form of a verb. In the active, the subject of the verb is the person or thing doing the action, while in passive the action is done to the subject.

According to Hasan and Saranya (2015) stated that English language has two voice, such as active and passive. Hidayat $(2008: 256)$ stated that the passive voice is a verb form that indicates that the subject of a sentence it suffered as a result of an action or work. The essential components of the English passive voice are a form of the auxiliary verb be (or sometimes get), and the past participle of the main verb indicate the action. Although the passive voice is less common than the active voice, there are several good reasons to sometimes use the passive.

\subsection{The Passive Sentences with indefinite agents.}

Not every sentence in the passive sentence names the agent or performer of the action in a by - phrase. The agents are not known perfectly or unclear means that the doer of some action doesn't know clearly and usually this sentence has a universal meaning.

According to A.J.Thomson (1986:266): “The passive is used:

1. When it is not necessary to mention the doer of the action as it is obvious who he is/was/will be... 
2. When we don't know, or don't know exactly, or have forgotten who did the action...

3. When the subject of the active verb would be 'people'

4. when the subject of the active sentence would be the indefinite pronoun

5. When we are more interested in the action than the person who does it.

6. The passive may be used to avoid an awkward or ungrammatical sentence.

7. The passive is sometimes preferred for psychological reason. A speaker may use it to disclaim responsibility for disagreeable announcement."

The passive sentences with indefinite agents can be transformed into active sentences by using somebody, anything, and something according to the text as its subject.

[a] My lunch is eaten (passive voice)

[b] Somebody ate my lunch (active voice)

From this example, sentence (a) is the pattern of passive sentence that has indefinite agents because there's no an agent or a doer in the sentence (byphrase), if the sentence (a) is changed into active sentence it will be "Somebody ate my lunch" like the sentence (b). The subject will be "somebody" that refers to if there's indefinite person who ate his lunch.

\subsection{The Passive Sentences with gerund}

Gerund is a verbal noun. The forms of gerund are like the participle forms, but the gerund is used as a noun - subject, predicate noun, direct object, object of a preposition, or appositive.

A passive sentence with gerund can be classified with two classification, they are:

a. Passive gerund with the verb need, want, require, deserve, and worth. In this pattern "to be" is not used and the verbs are followed by gerund from the verb before.

b. the passive gerunds are the helping verb on to be in the gerund pattern.

The writer wants to give the examples that can explain this classification such as:

a. I don't like being cheated

b. She always does everything without being told.

From the above example are passive sentences although it uses gerund as the passive sentence's construction.

\subsection{Horong Ni Hula Hula}

Indonesia is consisted of many kinds of tribes, which spread out in the whole country. The diversity of culture in Indonesia can be seen from many customs, religions, ethnic groups, roles and relationship between individuals. The Batak ethnic consists of Batak Toba, Batak Karo, Batak Simalungun, Batak PakpakDairi, and Batak AngkolaMandailing. Each ethnic has many similarities and differences in their languages, cultures, traditions, habits, ceremonies, and the roles for all unity. The similarities and differences caused by history, geography, and religion.

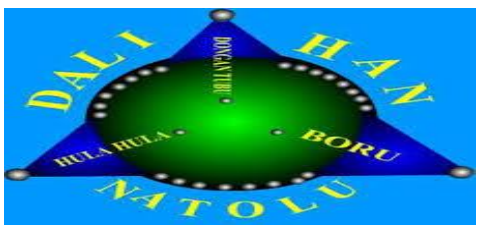

Figure 1. The Diagram of Dalihan Natolu

According to Figure 1.2. it is a diagram of Dalihan Natolu that is consisted of Dalihan Natolu's Principle. The principle of Dalihan Natolu is a legal subsystem that is rooted in community life in Batak Toba area, contains legal values that govern how Batak Toba customary law community should behave and there is also a division of tasks in resolving conflicts that are in the bonds of kindship in society as well as containing ways of resolving conflicts within the kinship system.

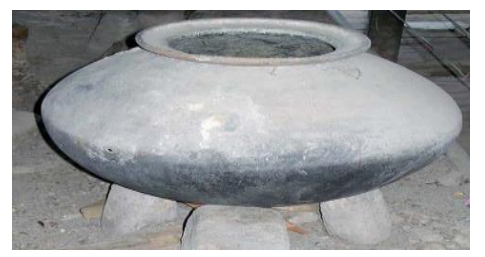

Figure 2. Furnace and Three Stones

Based on Figure 1.3. Furnace and three stones is a picture of Dalihan Natolu diversion, as we know, in Batak Toba Wedding Ceremony, Dalihan Natolu as the Batak Toba ideology is a framework that includes blood relatives and marital relationship that link one group. In Batak Toba tradition, Dalihan Natolu is determined by the existence of three functional positions as a social construction consisting of three things:

\section{Somba Marhula hula}

some interpret this understanding as "worshiping Hula-Hula, but this is not correct. The true minded of "Somba" which emphasizes the word "som" means worship, but the word "somba" itself emphasizes "ba" which is an adjective and means respect. So that Somba Marhula-hula means respect for Hula-Hula in their language, attitude and how they sat. Hula hula is the wife's 
clan group, starting from our wives, the mother's (father's wife) clan group, the wife grandparents' clan group, and several generations. Hula hula as a source of hagabeon /descent. Descendants were obtained from wife who came from the hula-hula. Without the hula-hula, there is no wife.

2. Elek Marboru

Elek marboru means to be gentle towards women. It means affection that is not accompanied by hidden and selfless intentions. Boru are our daughters or clan groups who take the wives of our children (our daughters). A gentle attitude towards boru is necessary, because in the past, boru who could be expected to help work in the fields. Without boru / daughters, throwing a party is impossible.

3. Manat mardongan tubu / sabutuha

A cautious attitude towards fellow clans to prevent misunderstanding in the implementation of traditional events, there is a statement "hau na jonok do na boi marsiogosan" which means the wood that is close can be rubbed. This illustration means how close and frequent relationships occur. That's possible to have conflicts, conflicts of interest, position, etc.

The core of Dalihan Natolu philosophy is moral principle containing the teaching of mutual respect "masipasangapon" supported by moral principles, mutual respect and help. Dalihan Natolu is a media that contains objective legal principles.

Batak tribe has a standard customary culture philosophy and is used as a life requirement called "Dalihan Natolu". This Dalihan Natolu philosophy is a life principle that can penetrate the religious barriers of beliefs of the different Batak tribes in the brotherhood of fellow Batak tribes., the majority of whom are part Christian, again, there are muslims who adhere to Malim religion (followers are usually called by Parmalim) and animists (called by Pelebegu or Parbegu).

According to Benyamin. 2016 in their Journal “ Konstruksi Makna Nilai Nilai Falsafah "Dalihan Na Tolu" Bagi Batak Perantau Di Kota Jakarta" said that generally, Dalihan Na Tolu interpreted as a life guide for clarifying kinship relations between religious communities and means of conflict resolution.

Horong Ni Hula Hula in Batak Toba culture is the male family of wife or mother, commonly referred to as tuggane by the husband and the uncle tulang by the son of Hula Hula, is a group of people whose position is highly respected by the family. Clan of wife's side so that in daily life, we also find a term called somba marhula hula which mean respect for wife in order to obtain safety and welfare.
Firstly, culture for Batak Toba tribe was a habit and behavior of the group's role which then grew up as the group's habit and carried out by all members of the community which eventually becomes a custom, thus custom are a habit of the community concerned which is carried out in a traditional wedding ceremony that is used to encourage an orderly life in holding social relations in Batak Toba community who view customs as a habit in their daily life.

\subsection{Passive Voice in Batak Toba Language}

According to international journal of physiology rehabilitation, Vol. 24, issues 08, 2020, Tiarnita Maria Sarjani Siregar, Mulyadi, Batak Toba has verb-initial, VOS word order, as in many Austronesian languages.

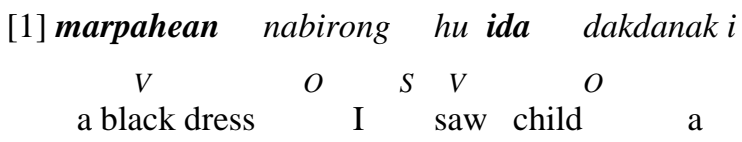

[I saw a child who is wearing a black dress]

[2] hu bereng dipake dakdaknak i pahean nabirong

$$
\begin{array}{cccrcc} 
& S & V & V & S & \\
\text { I } & \text { saw } & \text { was worn child } & \text { a } & \text { a black dress }
\end{array}
$$

[I saw a black dress was worn by a child]

Data [1] is active sentence which is the formulation; verb "marpahean" (was wearing) preceded subject "dakdanak i" (a child), while data [2] is passive sentence which is formulation be + Past Participle + By Phrase; "dipake" refers to was born (tobe past participle) and "dakdanak $i$ " refers to by child (by phrase). In Batak Toba Language (BTL) tobe + past participle "was worn" preceded by phrase "dakdanaki" then followed by object "pahean nabirong."According to data [1] the construction of active is VOSVO and from data [2] the construction of passive is SVVSO.

\section{[3] boru-boru i manuhor aek na tonggi tu kode $\begin{array}{llll}S & V & O & \end{array}$ \\ Woman the bought water mineral to shop nisi Ambarita \\ Ambarita's}

[the woman Bought mineral water to Ambarita's shop]

$\begin{array}{cccc}\text { [4] aek na tonggi } & \frac{\text { dituhor }}{V} & \text { si boruboru } i & \text { sian } \\ S & V & O & A d v \\ \text { Water mineral was bought } & \text { woman the from }\end{array}$

kode nisi Ambarita

shop Ambarita's 
[mineral water was bought by the woman from Ambarita's shop]

Data [3] is active sentence which is the formulation; verb "manuhor" (bought) preceded subject "boru boru i" (the woman), while Data [4] is passive sentence which is formulation be + Past Participle + By Phrase; "dituhor" refers to was bought (be past participle) and "boru boru $i$ " refers to by her / by the woman (by phrase). In Batak Toba Language (BTL) be + past participle "was bought" is put before by phrase "boru boru i" and object "aek na tonggi." is put in the beginning of the sentence or as the Subject in passive. According to data [3] the construction of active is SVOAdv and from data [4] the construction of passive is SVOAdv.

\subsubsection{Definite Agents}

The passive concept referred to in this article is a passive concept which is based on the view of the functional dysfunctional theory. The passive theory views passive and active construction as different constructs where passive construction is not derived from active construction. In this case, the patient who appears at the subject's position is not derived from the active structure object, but the patient's appearance on the subject's function in PC is present as the demands of the passive structure itself. The passive structure is what leads to the subject being the agent.

$\begin{array}{cccc}\text { [1] dituhor amanta } i & \text { mobil na bottar } & \text { saminggu } \\ \mathrm{V} & \mathrm{O} & \mathrm{S} & \mathrm{Adv} \\ \text { was bought man the } & \mathrm{car} & \text { white } & \text { last week } \\ \text { naung salpu } & & & \end{array}$

[a white car was bought by man last week]

According to data [1] definite agent is "amanta $i$ " (by the man), in the other word, the word " $i$ " refers to by and the verb "dituhor" (was bought) was placed in front of by phrase then followed by object "mobil na bottar $i$ " (a white car). From data (1), the construction of Passive is VOSAdv.

\begin{tabular}{|c|c|c|}
\hline [2] ditangihon & dakdanak $i$ & hata dainang \\
\hline$V$ & $O$ & $S$ \\
\hline ere heard & child & words mommy \\
\hline
\end{tabular}

[mommy's words were heard by a child]

According to data [2] definite agent is "dakdanak $i$ " (by the child), in this case the word " $i$ " refers to by and the verb "ditangihon" (were heard) was placed in front of by phrase then followed by object "hata dainang" (mommy's word). From data [2], the construction of Passive is VOS.

\subsubsection{Indefinite Agents}

Agent represents the person or a thing that performs the action and is the subject of an active sentence. The majority of the passive sentences don't have any agent. However, we use the agent when it is an indefinite noun phrase, an unexpected inanimate noun or the proper name of a widely known person.

$\begin{array}{ccc}{[1] \frac{\text { dipature }}{V}} & \text { jabuki } & \text { nabodari } \\ & S & A d v\end{array}$

was repaired my house yesterday

[my house was repaired yesterday (by someone)]

Data [1] is passive construction with indefinite agent. The utterance here wanted the listener know that someone was repaired his house last day. In this sentence, the agent was not important to know, the important thing was the action "dipature" (was repaired), the utterances want to emphasize the action. From data [1], the construction of Passive is VSAdv.

$\begin{array}{cc}\text { [2] ndang dibege } & \text { hataki } \\ -V & S \\ \text { wasn't heard } & \text { my words }\end{array}$

[my words wasn't heard (by somebody)]

Data [2] is passive construction with indefinite agent. The utterance here wanted the listener know that somebody wasn't heard his words. In this sentence, the agent was not important to know, the important thing was the action "ndang dibege" (wasn't heard), the utterances want to emphasize the action and his pique. From data [2], the construction of Passive is VS.

\subsection{Batak Toba Wedding Ceremony}

Every tribe in Indonesia has their own tradition to show their marriage custom. This is exactly influenced by their graphical condition, religion, habitual, and language. Every tribe said that marriage is a sacred ceremony, because marriage is inseparable from human life. Marriage Duvall \& Miller (1985), "Marriage is a socially recognized relationship between a man and a woman that provides for a sexual relation, legitimized childbearing and establishing a division of labor between spouses."

As we know, marriage is very important for all human because marriage is the only way to continue descent. Marriage is cultural heritage. In addition, marriage is a sacred thing and that unites two human beings and one of the important events in human life, to obtain or continue descent family. In Batak Toba wedding ceremony is so many processes before and after marriage ceremony. Process carried out before the wedding ceremony was Mangaririt, Mangalehon 
tanda, Marhusip, Martumpol, Marhata Sinamot, Martonggo Raja, Marsibuhai-buhai. In wedding ceremony is Giving Tudu-Tudu Ni Sipanganon, Giving Dengke, Eating Together, Dividing Jambar, Manjalo Tumpak, Pingan Panungkunan, Giving Ulos. The process after the wedding ceremony is paulak une and stepping stairs. The process is to make it easier for the community to settle obligations according to the applicable marriage customs.

Carle.2001 also states that the ceremonies of Batak people differ in detail but has some basic elements in common, such as the self - representative of three social kinship groups. "Dalihan Natolu" is those who do not honor their wife's relatives will find it difficult to earn their living. The description and the function of Dalihan Natolu namely Horong Ni Hula hula (in law families) as law principle or ideology of Batak Toba people tradition has the guidance of the social life from birth and till death

Hutajulu (2008:1) stated that in the tradition of marriage, the Batak Toba community adheres to the concept that marriage bond of Dalihan Natolu diversion elements from two extended families of individuals who will marry ritual objects that are often used in the Batak Toba wedding ceremony tradition as a transactional process is rice, ulos (shawl is a typical Batak Toba woven), meat, and money. Each individual who attend this ceremony must bring and receive all the things. In other words, wedding ceremony in Batak Toba tribe used an exchanged transaction system which is marked by tuhor tradition or giving a dowry by the groom's family.

Jerry Wilson in his Journal "Interpretation of Proverbs as Moral Messages and Character-Building Motivation: Batak Toba Marriage Customs in Indonesia" (2015, vol 6) said that One thing that must be known about Batak customs is in the party they have before a ceremony. Batak people always begin a traditional event by having a meal beforehand. The party organizers and host serve big meals to their guests, the purpose of which is to get pasu-pasu (blessings) and to respect their guests. They always serve rice and meat that can be beef or pork. And they also serve jambar, (a piece of meat presented to guests), which is already arranged and divided according to the status of the guests, such as: boru (the women's party, of wives) and paranak (the men's party of husband's), tulang (uncles), tulang rorobot and bona tulang (father's and mother's uncles of the host), suhut (the host), parsahutaon (the community helpers during the party).

\section{RESEARCH METHODOLOGIES}

Finding the data are a very important tasks to go through to make study of linguistics' problems. Since the researcher had made the decision to research the construction of passive voice of Batak Toba Language in wedding ceremony. She had collected the data which related to her subject for her thesis. The method was based on The Passive Voice Constructions of Horong Ni Hula Hula utterances in Batak Toba Wedding Ceremony.

\section{TECHNIQUE OF COLLECTING DATA}

In qualitative research, collecting the data mostly was done in participant observation, depth interview and documentation.

1. Interview

Interview is activity that involves interviewer and interviewee where the interviewer will give some questions to be answered by interviewee. Ary et.al (1985: 342) stated "In an interview, data are collected through face-to-face or telephone interaction between the interviewer and the respondent". Thus, in this case, the interviewer has to conduct collecting data with doing interaction or communication directly. But, it could be conducted face to face or through via electronic. In this research, Horong Ni Hula Hula such as Tulang, Bona Tulang, Bona ni Ari and Hula Hula were interviewed by researcher to know why they used passive voice construction in their utterances in this wedding ceremony.

2. Observation

Observation is the action or process of observing someone or something carefully to gain information which is influenced by the knowledge. Narbuko \& Achmadi (2010:70) said that observation is the tool to collect data which is done by observing and noting down systematically the phenomenon that is inquired. It meant that observation was used to collect the data in systematic way to understand and interpret actions, interaction or the meaning of event. For observation, the researcher made some note of Horong Ni Hula Hula utterances of Passive voice construction such as Tulang, Bona Tulang, Bona ni Ari and Hula Hula utterances which were used passive voice.

3. Documentation

A valuable source of information in qualitative research can be documentation. Sugiyono (2008: 240) stated that documentation can be written and picture by someone that can be used to obtain information. In conducting documentation method, the researcher could provide magazines, books, documents, etc. The function of documentation method was to make credible the result of observation or interview. In this research, the documentation guide was subjects' Batak Toba Horong Ni Hula Hula utterances such as Tulang, Bona Tulang, Bona ni Ari and Hula Hula utterances in using passive voice constructions and 
also a video of Batak Toba wedding ceremony which was used as the basic data of this research.

\section{TECHNIQUE OF ANALYZING DATA}

The data would be analyzed by:

1. Data Condensation refers to the process of selecting, focusing, simplifying, abstracting and transforming the raw data.

a. Selecting

In this section, the researcher selected all the passive voice clauses which were used by Horong ni Hula Hula utterances such as Parsinabung (prh); Tulang (tl), Bona Tulang (bnt), Bona ni Ari (bna) and Hula Hula (hh) in Batak Toba wedding ceremony.

b. Focusing

Focusing means that the researcher paid attention to the appropriate data. In this study, the researcher focused on passive utterances only, then grouped the passive utterances into their perspective groups after that compared their constructions. In this study, the researcher grouped the passive utterances by Horong Ni Hula Hula in Batak Toba wedding ceremony into several different construction groups. In this study, the researcher also grouped several constructions which had same construction into one group.

c. Simplifying

The researcher in this research made some group based on the types of passive voice construction. For example, in the study, there were five data that had same construction, so that, the researcher named them in one name.

d. Abstracting

In this section, there was a process where all the concrete data will become abstract data. The data which was analyzed abstracted to get the findings of research well. The passive voice constructions which were used by Horong Ni Hula Hula utterances in Batak Toba wedding ceremony.

e. Transforming

In this section, the researcher will transform the data into display with the analysis of the passive voice constructions which were used by Horong Ni Hula Hula utterances in Batak Toba wedding ceremony

\section{Data Display}

Data display is the process to simply the data in form of sentence, narrative or table so that it can be understandable. Sugiyono (2008:249) stated that in qualitative research, the most frequent form of display is narrative text. Hence, in the research, the researcher categorized the passive voice constructions into some types and made note each of kinds of them.

\section{FINDING AND DISCUSSION}

The researcher took data from Horong Ni Hula Hula utterances who were conswasted by 5 people, they were Parsinabung or Parhata (prh) can be as Tulang in this party, Hula Hula (hh), Tulang (tl), Bona Tulang (bnt) and Bona Ni Ari (bna). In this research, Parsinabung took a part as speakers and dominantly spoke in the ceremony. Parsinabung in here had a big authority in the ceremony because they run Batak Toba wedding ceremony, Parsinabung as a traditional speaker who was chosen through a tiered agreement starting from the closest circle or temple experts or having a celebration (hasuhuton) to the top level in one ompu or one Batak Toba clan group. The data was taken at Frans and Nensi Marriage as Batak Toba people tradition and the location of the party was Balimbingan, Tanah Jawa, Pematang Siantar. From the party document, the researcher found 59 passive voice clauses which were used by Horong Ni Hula Hula utterances. The researcher divided the constructions of passive voice who were used by Horong Ni Hula Hula became two parts and made the percentages of each part. The Constructions of passive voice occurred by Horong Ni Hula Hula could be seen in this Following table:

Table 1. The Construction of Passive Voice used by Horong Ni Hula Hula

\begin{tabular}{|c|c|c|c|c|c|c|c|}
\hline \multirow[b]{2}{*}{$\begin{array}{l}\mathbf{N} \\
\text { o. }\end{array}$} & \multirow{2}{*}{$\begin{array}{l}\text { HN } \\
\text { HH }\end{array}$} & \multicolumn{6}{|c|}{ The Construction of Passive Voice } \\
\hline & & $\begin{array}{l}\text { PV } \\
\text { DA }\end{array}$ & $\begin{array}{c}\text { Perc } \\
\text { ent }\end{array}$ & $\begin{array}{l}\text { PV } \\
\text { IA }\end{array}$ & $\begin{array}{c}\text { Perc } \\
\text { en }\end{array}$ & $\begin{array}{c}\text { Tot } \\
\text { al }\end{array}$ & $\begin{array}{c}\text { Perc } \\
\text { ent }\end{array}$ \\
\hline 1. & Prh & 31 & $\begin{array}{c}57.4 \\
0 \%\end{array}$ & 3 & $\begin{array}{l}60 \\
\%\end{array}$ & 34 & $\begin{array}{c}57.6 \\
2 \%\end{array}$ \\
\hline 2. & $\mathrm{Hh}$ & 5 & $\begin{array}{c}9,25 \\
\%\end{array}$ & 0 & $0 \%$ & 5 & $\begin{array}{c}8.47 \\
\%\end{array}$ \\
\hline 3. & $\mathrm{Tl}$ & 13 & $\begin{array}{l}24.0 \\
7 \%\end{array}$ & 1 & $\begin{array}{l}20 \\
\%\end{array}$ & 14 & $\begin{array}{c}23.7 \\
2 \%\end{array}$ \\
\hline 4. & Bnt & 2 & $\begin{array}{c}3.70 \\
\%\end{array}$ & 1 & $\begin{array}{l}20 \\
\%\end{array}$ & 3 & $\begin{array}{c}5.08 \\
\%\end{array}$ \\
\hline 5. & Bna & 3 & $\begin{array}{c}5.55 \\
\%\end{array}$ & 0 & $0 \%$ & 3 & $\begin{array}{c}5.08 \\
\%\end{array}$ \\
\hline & otal & 54 & & 5 & & 59 & \\
\hline
\end{tabular}




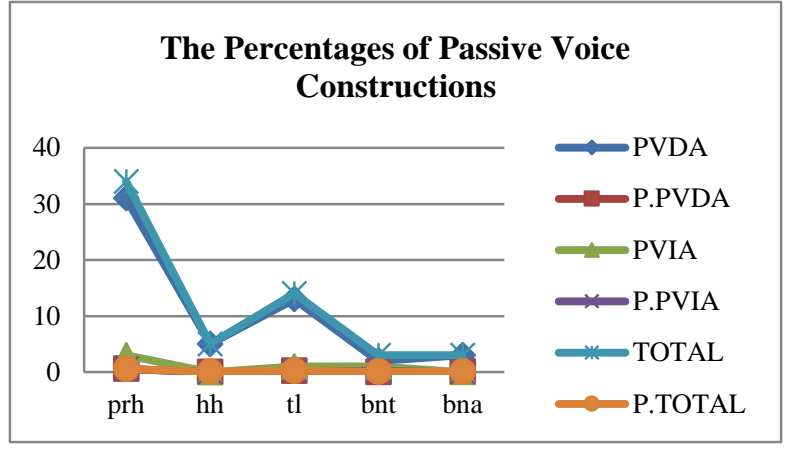

Figure 3. The Percentages of Construction of Passive Voice used by Horong Ni Hula Hula

From Figure 4.1. we found 59 data which were divided by two contructions, they were Passive Voice with Definite Agent (PVDA) amounts 54 data and 5 data for Passive Voice with Indefinite Agent (PVIA) From the chart above, the dominant construction of passive voice were used by Horong Ni Hula Hula utterances in Batak Toba wedding ceremony was passive voice with definite agent (PVDA) and it was used by Parsinabung (prh) with 31 clauses in $57.40 \%$ in its percentages. The lowest passive voice with definite agent (PVDA) was used by Bona Tulang (bnt) with 2 clauses in $5.55 \%$ in its percentages while for the highest percentages in Passive Voice with Indefinite Agent (PVIA) was used by Parsinabung (prh) with 3 clauses in $60 \%$ and the lowest percentages in Passive Voice with Indefinite Agent (PVIA) was used by Hula Hula (hh) and Bona Ni Ari (bna) with 0 clause in $0 \%$.

\section{CONCLUSION}

In Batak Toba wedding ceremony, there were two types of passive voice, they were passive voice with definite agents or back ground and passive voice with indefinite agents or fore ground, so the dominant construction of passive voice were used by Horong $\mathrm{Ni}$ Hula Hula utterances in Batak Toba wedding ceremony was passive voice with definite agent (PVDA) and it was used by Parsinabung (prh) with the total utterances was thirty one utterances of passive voice in $57.40 \%$ in its percentages because of their authority running a wedding ceremony, in this case Parsinabung was as a vice speaker of both family clan, Parsinabung also controlled a ceremony from beginning until the ending. It is contrasted with the percentage of Bona Tulang (bna) with the total utterances was two utterances of passive voice in $3.70 \%$ because of their time is limited in Batak Toba Wedding Ceremony, Bona Tulang (bna) had an important part in Batak Toba wedding ceremony and they presented just only once and gave ulos (shawl) as the symbol of their blessing to families.

\section{REFERENCES}

[1] A.Scholastic. 2018. Learning the English Passive Voice: Difficulties, Learning Strategies of Igbo ESL Learners and Pedagogical Implications. International Journal of English and Literature. Vol. 9, PP 50-62

[2] Abulazim, O.Y.2019. Error Analysis of Passive Voice employed by University Students' in Writing Lab Reports: A Case Study of Sudan University of Science and Technology (SUST) Students' at Faculty of Sciences, Chemistry Department. Canadian Center of Science and Education, Vol. 12, No. 7

[3] Alhussain, A. 2016. A Syntatic Study of The Passive Voice in Modern Standard Arabic (MSA). International Journal of English Language and Linguistics Research, Vol.4 No.3, pp. $21-31$

[4] Burridge,K. 2016. Euphemism and Language Change: The Sixth and Seventh Ages. Lexis: Euphemism as a word Formation Process, Vol.7

[5] Chomthong. D. 2011. A Case study of Learning English Passive of Thai EFL Learners: Difficulties and Learning Strategies. The Asian Conference on Language Learning Official. Vol.4.

[6] Jerry,W. 2017. Interpretation of Proverbs as Moral Messages and Character-Building Motivation: Batak Toba Marriage Customs in Indonesia. International Journal of Science and Research (IJSR), Vol 6 Issues 12

[7] Mulyadi. 2020. Passive Construction of Batak Toba Language. International Journal of Psychosocial Rehabilitation, Vol. 24, issues 2008. 